\title{
Damage Assessment from Storm Surge to Coastal Cities: Lessons from the Miami Area
}

\author{
Elisabetta Genovese ${ }^{1}$, Stéphane Hallegatte ${ }^{1,2}$, Patrice Dumas ${ }^{1,3}$ \\ ${ }^{1}$ Centre International de Recherche sur l'Environnement et le Développe- \\ ment (CIRED) \\ ${ }^{2}$ Ecole Nationale de la Météorologie, Meteo France \\ ${ }^{3}$ Centre de Coopération Internationale en Recherche Agronomique pour le \\ Développement (CIRAD) \\ genovese@centre-cired.fr, hallegatte@centre-cired.fr, dumas@centre- \\ cired.fr
}

\begin{abstract}
Coastal cities are growing at a very rapid pace, both in population and in terms of assets; therefore, flood risk is likely to increase substantially in these areas in the absence of specific protections. In addition, great uncertainty surrounds the future evolution of hurricane intensity and sea level rise. The area of Miami represents a clear hotspot of human and economic coastal flood exposure: there are more than 5 million inhabitants in the Miami metropolitan area and the population is growing. It is also a low-lying city with most of the population living below an elevation of $10 \mathrm{~m}$ and is located in a region where tropical cyclones hit frequently. The present study is focused on the two contiguous counties of Miami, Dade and Broward. In this analysis, we consider the impact of different storm surges predicted by the computerized model SLOSH ${ }^{1}$ and investigate flood risks with current sea level, considering different hurricane parameters (storm category and direction, wind speed, and tide level). For each impact, we apply a damage function and determine if the considered storm surges potentially lead to asset loss, considering both properties and their contents. The results show that, in absence of protections, losses will be very high for large storm surges reaching up to tens of billions USD. In the second part of the analysis, we demonstrate how the economic impact
\end{abstract}

${ }^{1}$ http://www.nhc.noaa.gov/HAW2/english/surge/slosh.shtml 
changes when protections are built up, considering different dams' heights. We conclude that raising flood defences would be beneficial, since the consequences of a storm surge could be enormous.

\section{Introduction}

It is very likely that flood risks will increase in coastal cities in the next years, because of demographic, socio-economic, and environmental trends (Webster et al. 2005; Nicholls et al. 2007). The assessment of this increase is necessary in order to include the range of possible changes within urban and land-use planning (Lugeri et al. 2010). Moreover, urbanization and population in these areas are still growing at a very rapid pace, driven by economic opportunities and the development of international trade. Therefore, the product of an interaction between numerous aspects, such as climatic, socio-economic, and institutional, is increasing the risk of big damage losses (Lugeri et al. 2006) and it is suitable to reduce future risks through targeted territorial development plans. This article proposes the case of the Miami area illustrating a methodology to assess coastal flood risks in urban areas and it aimes to derive more general lessons, useful for all coastal cities.

Since 1990, Florida has been struck directly by 22 tropical storms and hurricanes. In 1992, Hurricane Andrew hit Dade County with Category 5 force, generating 17-foot (more than 5 meters) storm surges. 23 people were killed and property damage in the whole state of Florida from Andrew was estimated at 25.5 billion USD. The marine ecosystem, including the natural reef, was also heavily damaged. Between August and September 2004 several hurricanes struck the Florida coast (see Table 1). Eventually, 45 people were killed and estimated damages across the southeastern United States totalled over 21.1 billion USD ${ }^{2}$.

Even before the recent hurricane seasons, $40 \%$ of Florida's beaches were listed as critically eroded. In 1986, the Florida Legislature adopted a complete beach management planning program to protect and restore the state's beaches ${ }^{3}$. Between 1994 and 2004, Florida began the largest and most costly beach and dune rebuilding program in US history: 242 million USD were spent on beach nourishment, aiming to absorb the wave energy dissipated across the surf zone. Following the catastrophes of 2004, there was a hurry to immediately restore damaged beaches. In 2004 and 2005,

\footnotetext{
${ }^{2}$ http://www.edf.org/article.cfm? contentid=5361

${ }^{3}$ http://www.dep.state.fl.us/beaches/programs/bcherosn.htm
} 
the state spent approximately 173 million USD on sand ${ }^{4}$ and over 582 million USD in 2006 for beach erosion control activities and hurricane recovery 5 .

Table 1. Florida major hurricanes in the last 100 years ${ }^{6}$.

\begin{tabular}{|l|c|c|c|l|}
\hline \multicolumn{1}{|c|}{ Storm } & Category & Year & $\begin{array}{c}\text { Landfall } \\
\text { Intensity }\end{array}$ & \multicolumn{1}{|c|}{ Landfall Location } \\
\hline Andrew & $\mathbf{5}$ & 1992 & 145 & Homestead \\
\hline Labor Day & $\mathbf{5}$ & 1935 & 160 & Craig Key \\
\hline Charley & $\mathbf{4}$ & 2004 & 130 & Cayo Costa \\
\hline Donna & $\mathbf{4}$ & 1960 & 120 & Key Vaca \\
\hline Unnamed & $\mathbf{4}$ & 1949 & 130 & Palm Beach Shores \\
\hline Unnamed & $\mathbf{4}$ & 1947 & 135 & Pompano Beach, Florida \\
\hline Unnamed & $\mathbf{4}$ & 1945 & 120 & Upper Florida Keys \\
\hline Okeechobee & $\mathbf{4}$ & 1928 & 130 & Jupiter Island \\
\hline Great Miami & $\mathbf{4}$ & 1926 & 115 & South Miami \\
\hline Unnamed & $\mathbf{4}$ & 1919 & 130 & Offshore Florida Keys \\
\hline Dennis & $\mathbf{3}$ & 2005 & 105 & Santa Rosa Island \\
\hline Wilma & $\mathbf{3}$ & 2005 & 105 & Cape Romano \\
\hline Ivan & $\mathbf{3}$ & 2004 & 105 & Gulf Shores, Alabama \\
\hline Jeanne & $\mathbf{3}$ & 2004 & 105 & Hutchinson Island \\
\hline Opal & $\mathbf{3}$ & 1995 & 100 & Pensacola Beach \\
\hline Elena & $\mathbf{3}$ & 1985 & 100 & Gulfport, Mississippi \\
\hline Eloise & $\mathbf{3}$ & 1975 & 110 & Bay County \\
\hline Betsy & $\mathbf{3}$ & 1965 & 110 & Upper Florida Keys \\
\hline Easy & $\mathbf{3}$ & 1950 & 105 & Cedar Key \\
\hline King & $\mathbf{3}$ & 1950 & 105 & Miami \\
\hline Unnamed & $\mathbf{3}$ & 1948 & 105 & Lower Florida Keys \\
\hline Unnamed & $\mathbf{3}$ & 1948 & 110 & Marathon \\
\hline Unnamed & $\mathbf{3}$ & 1941 & 105 & Goulds \\
\hline Unnamed & $\mathbf{3}$ & 1933 & 110 & Jupiter \\
\hline Unnamed & $\mathbf{3}$ & 1917 & 100 & Okaloosa Count \\
\hline & & & & \\
\hline & & & & \\
\hline
\end{tabular}

Despite the large amount of money invested, our study suggests that, in the case of storms with elevated water levels and high waves, beach nourishment does not provide adequate benefits in the form of storm damage

${ }^{4}$ http://www.surfrider.org/stateofthebeach/05-

$\underline{\text { sr } / \text { state.asp? } \text { zone }=\text { se\&state }=\text { fl\&cat }=\text { bf }}$

${ }^{5} \mathrm{http}$ ://www.dep.state.fl.us/beaches/programs/bcherosn.htm

6 Atlantic hurricane research division (2008). "All U.S. Hurricanes (18512007)". NOAA. http://www.aoml.noaa.gov/hrd/hurdat/ushurrlist18512007.txt. 
reduction and cannot be sufficient to avoid the water impact on structures and infrastructures.

The present study is focused on the area of Miami, which clearly represents a hotspot of human and economic coastal flood exposure (Herweijer et al. 2008). Its metropolitan area has a population of more than 5 million inhabitants. The number of inhabitants has grown by $35 \%$ since 1990 and it keeps growing; new residential and commercial constructions have been widespread.

According to an OECD global analysis of vulnerable coastal cities (Nicholls 2007), Miami is one of the port cities with the highest exposure and vulnerability to climate extremes in the world, even in the present situation. It is located in a region where tropical hurricanes hit frequently (see a statistical analysis of hurricane landfalls, in Hallegatte et al. 2007) and, in the future, it may be one of the most exposed areas to coastal flooding in terms of infrastructure and other assets.

Since Miami is also a low-lying city, with most of the population living below an elevation of 10 meters, hurricanes often cause significant storm surges and losses from these storms could be enormous in such a flat area. When considering its high exposure, the city has a surprisingly very low level of protection with no comprehensive seawall or dam system to protect the city from storm surges.

This paper focuses on current flood risks and describes the impacts of water-related risks in this region, specifically in the Miami Dade and Broward counties, with the aim to establish an overall cost-estimate of potential losses. In particular, the work focuses on the economic aspects of flood damages by investigating the value of physical assets affected by the event. To evaluate the cost of damages on direct losses in residential areas, we propose a damage assessment.

In the first part of this study, we analyse storm surge losses considering different hurricanes' intensities and directions, in order to estimate storm surge heights and winds, according to the result of the computerized model $\mathrm{SLOSH}^{7}$. Then, we assess the direct losses that could be caused by episodes of sea level rise at different levels, according to the economic values of insured properties provided by Risk Management Solution $(\mathrm{RMS})^{8}$. This analysis is used to determine the benefits from protection, in the current situation, as a function of different storm surges. Finally, we determine the consequences of an adaptation strategy starting from the current condition and then analyse how the loss prospective can change when protections are added. The study demonstrates that storm surges will

\footnotetext{
${ }^{7}$ http://www.nhc.noaa.gov/HAW2/english/surge/slosh.shtml

${ }^{8} \mathrm{http}: / /$ www.rms.com/
} 
lead to definitive losses of assets and our conclusion is that to take action and to raise flood defences are urgently required. In a follow-up analysis, climate change and sea level rise will be included, to investigate how these additional drivers modify the optimal defence strategy.

\section{The effects of climate change on sea levels and hurricanes}

The 2007 Fourth Assessment Report of the Intergovernmental Panel on Climate Change (IPCC) projected that global mean sea levels would rise by $18-59 \mathrm{~cm}$ above 1990 levels by the 2090s. However, these projections do not fully include contributions from the melting ice sheets (due to the limitations of the modelling techniques used). Rahmstorf (2007) employs a technique that observes the relationship between global sea levels and temperature to project future sea levels from temperature projections. While very simplistic, this technique has the advantage of using real data and avoiding many of the uncertainties introduced through using global climate models. Rahmstorf (2007) projects that global sea levels could increase by around $50-140 \mathrm{~cm}$ above 1990 levels by 2100 . Pfeffer et al. (2008) conclude that sea level rise cannot exceed $2 \mathrm{~m}$ in 2100 , with a best guess at $80 \mathrm{~cm}$.

Depending on the methodology and the model, hurricanes are predicted to become more intense, stable, or less frequent (see, e.g., Landsea 2005; Emanuel 2008). On top of climate-change-related changes in sea level, water height will continue to vary over time as a result of weather-related effects, including storm surges. Storm surge is water that is pushed toward the shore by the force of winds that swirl around the storm. This progressing surge combines with the normal tides to create the hurricane storm tide, which can increase the mean water level by 15 feet or more. Storm surge begins to grow when the hurricane is still far out at sea over deep water9. The low pressure near the centre of the storm causes the water to rise.

Climate change can also affect the amplitude of these variations by changing the frequency of the variability through, for example, changes in hurricane intensity. However, future modifications in water levels and hurricane intensities are still heatedly debated in the scientific community and cannot be easily anticipated.

$9{ }^{9} \mathrm{http}: / /$ slosh.nws.noaa.gov/sloshPub/SLOSH-Display-Training.pdf 
These trends make it necessary and urgent to assess how the city protections need to be upgraded. As a first step, however, an assessment of current risks is required. In the next section, we illustrate how storm surges can be predicted in the current situation by using modelling processes.

\subsection{Description of the SLOSH model}

SLOSH (Sea, Lake, and Overland Surge from Hurricanes) is a computerized model developed by the American National Weather Service (NWS) with the aim to estimate storm surge heights and winds resulting from historical, hypothetical, or predicted hurricanes ${ }^{10}$. SLOSH is used to define potential flooding from storm surge, for a given location, and from a threatening hurricane.

The SLOSH model contains topographic information for each grid cell. It calculates water surface elevations caused by storm surge in a specific basin and provides output data shown as color-coded storm surge in the SLOSH display (see Figure 1). The water depth indicated in each cell considers the elevation of the grid cell and the amount of water that is able to flow into that cell. For each cell an average water surface elevation is found and assigned to it. Accuracy for SLOSH is usually within +- $20 \%$ of the peak storm surge for a known hurricane track, intensity, and size, based on surge measurements from past hurricanes.

A SLOSH Basin is a geographical region where the values of topography, bathymetry, and a hurricane track (considering its pressure, radius of maximum winds, location, direction, and speed) are known. The point of a hurricane's landfall is crucial to determine which areas will be inundated by the storm surge. Data are available for 39 basins in the US.

The model gives as a result different MEOW (Maximum Envelope of Water) which refers to the maximum the water reaches at any point in time at every grid cell in the SLOSH Basin, for a given hypothetical storm. A MEOW is the set of the highest surge values at each grid location for a given storm category, forward speed, and direction of motion and plans for the worst-case scenario. We generated a MEOW for each storm category, storm direction, forward speed, and tide level available for the Bay Biscayne basin ${ }^{11}$.

${ }^{11}$ Forward speeds and storm categories were chosen according to shapefiles availability. Not all the categories and forward speeds are provided in a shapefile format. 


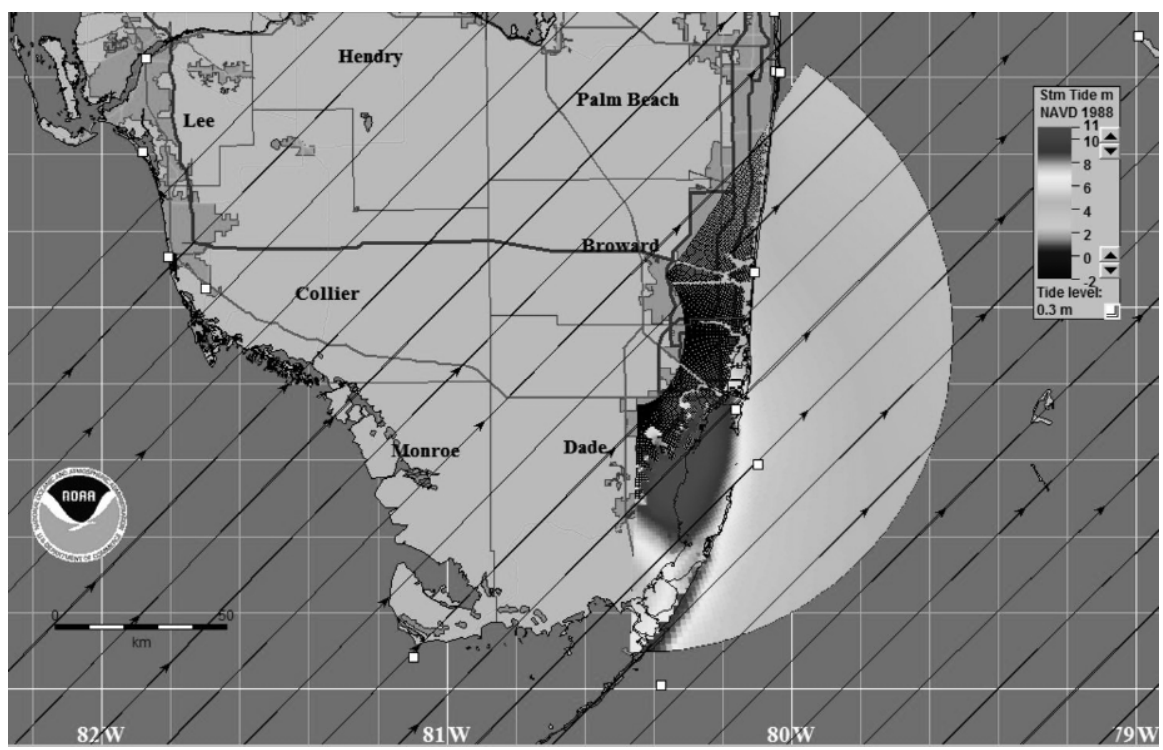

Fig. 1. Category 5 storm heading Northeast at a speed of $25 \mathrm{mph}$ (mean tide) on Biscayne Bay in the SLOSH display.

Local stakeholders and decision-makers in Miami-Dade County are aware of the vulnerability of their territory ${ }^{12}$ and they already applied SLOSH in their spatial planning activities. The Miami-Dade County storm surge evacuation zones were redrawn in 2003 following the information acquired through the SLOSH maps: each zone will be evacuated depending on the hurricane's track and projected storm surge. ${ }^{13}$

At present, there is no recognized central authority for climate change risk assessment and adaptation in the Miami metropolitan area. This is due to the USA's decentralization of water management, spatial planning, and related responsibilities.

Therefore, spatial planning and water services are handled by separate agencies. The climate change adaptation effort must engage each municipality and local governmental entity in assessing the impacts of climate on that entity's own responsibility. A multi-stakeholder task force convened by Miami-Dade County has issued preliminary adaptation recommendations and is looking for the collaboration of all local authorities (ICLEI 2009).

The results of our research show that, in the Miami-Dade County area, the Erosion Control and Hurricane Protection Project consists of restora-

\footnotetext{
${ }^{12} \mathrm{http}: / / w w w . m i a m i d a d e . g o v / d e r m /$ climatechange/taskforce.asp

${ }^{13} \mathrm{http}: / /$ www.miamidade.gov/oem/evacuation_zone.asp
} 
tion, ongoing maintenance re-nourishment, and structural improvements of the critically eroded shoreline ${ }^{14}$ without taking into account the creation of dams or seawalls.

According to ICLEI (2009), coastal cities and their national governments must not only strengthen their disaster preparedness, such as early warning and evacuation programmes in case of storm events, but also plan ways to handle land development for disaster prevention and to climate proof water. Therefore, both technical innovations and new institutional arrangements are urgently needed.

\section{Current flood risks in absence of protection}

As a first step, in order to determine flood potential damage in the counties of Miami Dade and Broward, we propose an assessment of the exposure, which is estimated here in absence of flood protection. The exposure is the measure of the values and the assets that would be affected by a flood (Kron 2003). In this analysis, exposure calculation is based on the portion of land that would be inundated in different hypothetical storm surge events.

The available economic data include only insured assets at this stage and were provided to us by RMS. Therefore, infrastructure and government assets are not included at this stage of analysis and will be included in Section 3.2 when analysing flood losses by percentage estimation.

We calculated the exposure considering several possible storm surge simulations (described in Section 2) provided by SLOSH for the Biscayne Bay and integrated in a GIS as shapefile (see Figure 2).

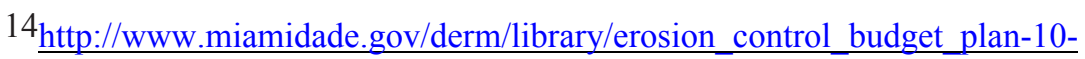
$\underline{11 . p d f}$ 


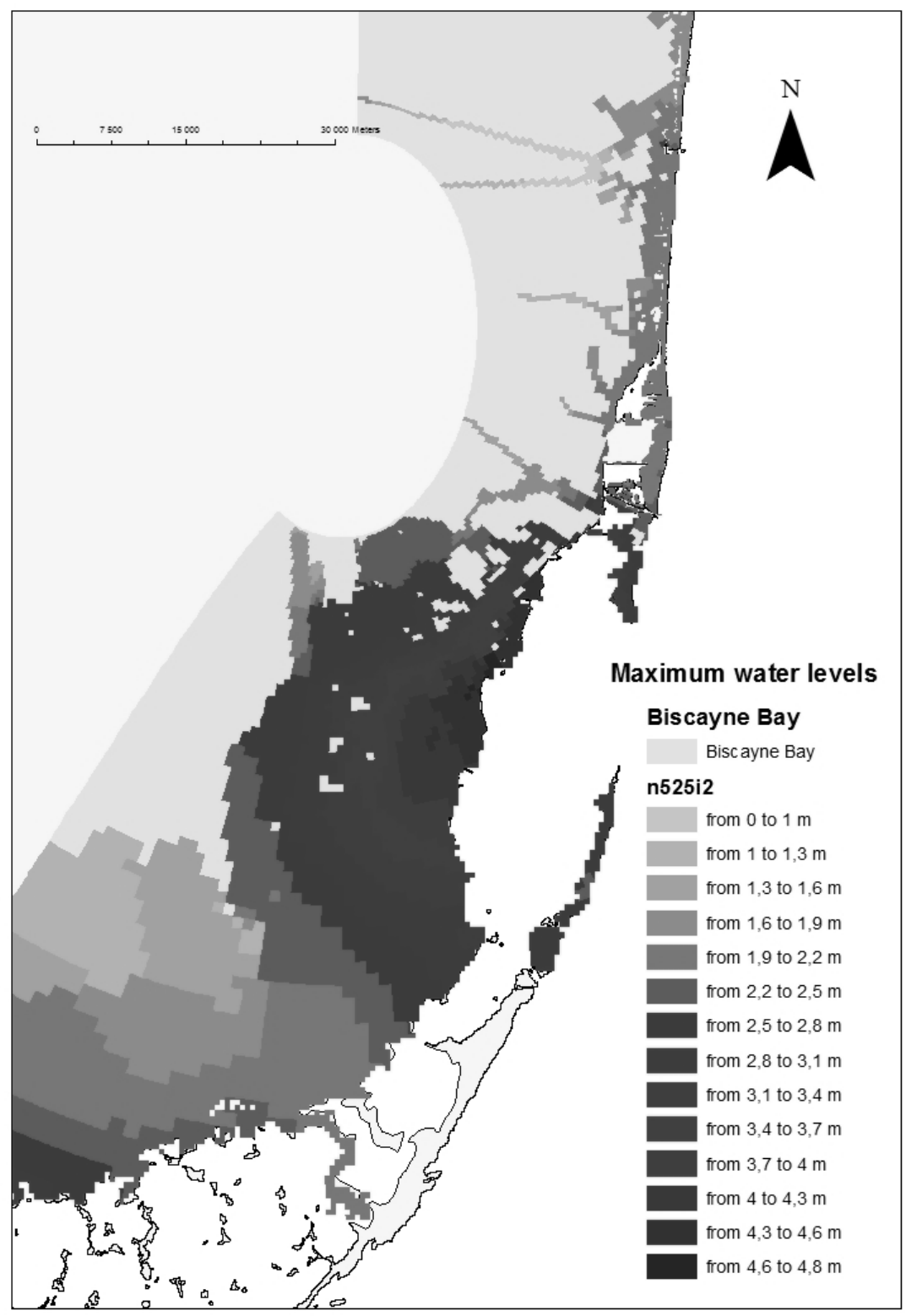

Fig. 2. Maximum water levels in the study area in case of a Category 5 storm heading Northeast at a speed of $25 \mathrm{mph}$ (mean tide). 
The SLOSH database exists in this area for different directions of the hurricane tracks: east, north-east, north, north-west, and west. Five hurricane "Categories" (between 1 and 5) and "Speed" (5, 15, and 25 miles per hour) are presented for these directions. We extracted the results in a shapefile format for different storm directions in order to assess the economic losses in case of weak (Category 1), medium (Category 3), or strong (Category 5) storm surge. Most MEOWs have the option of selecting high or mean tide. According to SLOSH training guidelines, that affirm that studies generally use the high tide option, we only considered the high tide results. ${ }^{15}$ Therefore we analysed all the high tide MEOWS for the abovementioned categories and here present the results and analysis for some of the most significant ones ${ }^{16}$.

We found the maximum levels that water can reach during the different events in each area. In the Biscayne Bay region, where floods are the largest, maximum water levels from 1 up to 2 meters can be reached in case of a Category 1 storm (depending on the wind direction), $2 \mathrm{~m}$ up to $3 \mathrm{~m}$ for a Category 3 , and even from $3.5 \mathrm{~m}$ up to $5 \mathrm{~m}$ in the extreme event of a Category 5 storm.

By an overlay of these results and the insured value of residential, industrial and commercial areas visualized on a GIS, we determined which current insured built-up areas are at risk of storm surge and estimated the economic insured value of the entire assets that are flooded by each storm surge category. These results are based on a very detailed economic database with a territorial scale of 100 and 500 square meters for the coastal area, and of 1 and $5 \mathrm{~km}$ for the hinterland. The economic results we obtained were weighted on a damage function related to water heights, as explained in the next section.

\subsection{Damage function}

There is a complex link between exposure to high sea level and the destruction and losses caused by such episodes. First, a building that is affected by a flood is not 100-percent destroyed. Thus, direct losses caused by an event have to consider a damage function where losses increase proportionally to water level. Due to the lack of information and the difficulty

\footnotetext{
${ }^{15} \mathrm{http}: / /$ slosh.nws.noaa.gov/sloshPub/SLOSH-Display-Training.pdf

${ }^{16}$ The first group of letters in the MEOW file name refers to storm motion direction, the next number represents the hurricane category, the next 2 numbers represent the forward speed, I0 refers to mean tide, I2 refers to high tide, and the file extension represents the basin.
} 
in integrating such variables, damage is generally related to only water depth (see for example Green 2003; Van der Sande et al. 2003; Genovese 2006). This basic methodology was outlined already in 1945 by White and is referred to as stage damage curve representing the relation between inundation depth and damage cost for a land use class.

The damage functions are increasing functions, which means that as the inundation depth grows, also damage rises. This value is based on the principle of replacement value: how much money it would cost to obtain the 'identical' object. The damage function has values included between 0 and 1 , with the value 0 if there is no damage and the value 1 if there is complete destruction of the asset. Stage-damage curves can be developed from actual flood events and then can be used to simulate damage for potential future events, even though this approach creates problems like extrapolation difficulties from place to place due to differences in warning time and in building type and content (Smith 1994).

Moreover, for storm surge, normally at least two vulnerability curves exist. For properties on the sea front, they will be more quickly destroyed as they will be exposed to wave action as well as flood waters - i.e. the force of the waves will damage the property. This is relevant for Miami since many expensive properties and hotels are located on the sea front. Properties inland will just be exposed to "resting" water damage. This is clearly represented in SLOSH results and fits well with our database of insured properties, where higher values are located in the beach area.

Furthermore, the heights of buildings have to be considered while choosing the damage function. In our study area, both small residential properties and skyscrapers are present; therefore, even if they would require separated vulnerability curves, we chose to use an average curve directly, in order to account for heterogeneity in the results.

We consider here the direct costs, which refer to physical damage to capital assets and inventories, valued at same-standard replacement costs. Indirect losses include those that are not provoked by the disaster itself, but by its consequences (Hallegatte and Przyluski 2010). At this stage, we do not consider indirect losses, such as business interruption, environmental damage, cleaning, and evacuation costs.

Also, only water level effects are considered, even if in case of storm other events can affect the properties, for example strong wind can damage houses' roofs.

During a flood event, some losses can be avoided by appropriate action from the people who live in the floodplain. Examples are the caravans and the cars, because usually there is enough time to remove them from the area that is going to be flooded. Therefore they are not taken into account of the damage assessment. An important question in damage calculation is 
which assumption has to be made with respect to the behaviour of the population. This is caused by the fact that damage is a function of many physical and behavioural factors, like the preparedness of a rapid and adequate response to a flood event (Genovese 2006). Hence, all uncertainties in the damage functions are not included in this analysis.

\subsection{Damage function application}

Among the damage functions available in the literature, we chose the one developed by the OECD for the area of Copenhagen (Hallegatte et al. 2008) because it considers water level until 5 meters (see Table 2) when the others existing in literature for coastal floods consider lower water levels. Of course the Miami area has peculiarities which would require a specific damage function, which we will develop in a following stage of the study. Since in Miami and Miami Beach skyscrapers are numerous and the average building height is probably higher than in Copenhagen, we assume that they will not be completely destroyed during a surge.

Table 2. Damage function for residential, commercial, and industrial structures (Hallegatte et al., 2008). As the inundation depth grows, the damage percentage rises.

\begin{tabular}{|l|c|c|c|c|c|c|}
\hline $\begin{array}{c}\text { Elevation } \\
\text { Range (m) }\end{array}$ & $\begin{array}{c}\text { Resi- } \\
\text { dential } \\
(\text { Structure) } \\
\%\end{array}$ & $\begin{array}{c}\text { Commer- } \\
\text { cial (Struc- } \\
\text { ture) } \\
\%\end{array}$ & $\begin{array}{c}\text { Indus- } \\
\text { trial (Struc- } \\
\text { ture) } \\
\%\end{array}$ & $\begin{array}{c}\text { Resi- } \\
\text { dential } \\
\text { (Content) } \\
\%\end{array}$ & $\begin{array}{c}\text { Commer- } \\
\text { cial (Con- } \\
\text { tent) } \\
\%\end{array}$ & $\begin{array}{c}\text { Indus- } \\
\text { trial (Con- } \\
\text { tent) } \\
\%\end{array}$ \\
\hline $\mathbf{0}$ & 0 & 0 & 0 & 0 & 0 & 0 \\
\hline $\mathbf{0 , 5}$ & 10 & 24 & 20 & 40 & 33 & 38 \\
\hline $\mathbf{1}$ & 12 & 40 & 40 & 48 & 55 & 67 \\
\hline $\mathbf{1 , 5}$ & 14 & 47 & 47 & 49 & 64 & 75 \\
\hline $\mathbf{2}$ & 15 & 54 & 53 & 50 & 73 & 82 \\
\hline $\mathbf{2 , 5}$ & 17 & 56 & 55 & 58 & 78 & 85 \\
\hline $\mathbf{3}$ & 18 & 58 & 57 & 67 & 82 & 88 \\
\hline $\mathbf{3 , 5}$ & 20 & 60 & 59 & 75 & 87 & 91 \\
\hline $\mathbf{4}$ & 22 & 61 & 61 & 83 & 91 & 94 \\
\hline $\mathbf{4 , 5}$ & 23 & 63 & 63 & 92 & 96 & 97 \\
\hline $\mathbf{5}$ & 25 & 65 & 65 & 100 & 100 & 100 \\
\hline
\end{tabular}

Moreover, we considered the maximum level that water reaches at every grid cell. Therefore, the results we obtained by using this damage function are probably overestimated.

Buildings were distributed in insurance classes, each with their own stage damage curve based on the type of asset (residential, commercial, 
and industrial). The contents and building costs have to be calculated separately since their vulnerability to floods are different.

For most residential buildings the most expensive contents are kitchens/heating systems and these assets are most of the time on the ground floor, so are quickly destroyed. For commercial and industrial activities, the difference is even higher since most of these activities are located on ground floors. Therefore, in the damage function, contents are evaluated as completely destroyed at water level that is considerably lower than the buildings themselves.

In order to fit this function to our study, it has been linearly interpolated: values for each 0.10 meters of water level were calculated and extended to 4.8 meters, which is the highest water level that can be potentially reached in case of a Category 5 storm with a north direction.

For each available MEOW, we calculated the total economic damage for different storms of Categories 1, 3, and 5. In Figure 3, we show content and structure damage estimations for storm surges of east and north-east directions, calculated for a low category and forward speed (categories 1 and $0,5 \mathrm{mph}$ speed), for a medium category (3) and $15 \mathrm{mph}$ speed, and for the highest hurricane Category 5 and $15 \mathrm{mph}$ speed.

The estimated direct losses amount to several billions of USD. In the first example, we illustrate that storms having aneasterly direction, in the current economic and land use situation, would cause direct losses to buildings amounting to about 2 to 5 billion USD for residential structures, 5 to 8 billion USD for commercial structures, and 2 to 3 billion USD for industrial structures (depending on storm category). Similarly for the contents, it would cost about 5 to 9 billion USD for residential contents, 4 to 6 billion USD for commercial contents, and 4 to 5 billion USD for industrial contents, for a total of 21 to 35 billion USD.

In the second example, for a storm with a north-east direction, the monetary results are a bit higher, especially for residential structures. The total sum of these results is enormous and shows that, without protection, storm surge increases flooding risks in a significant manner. 


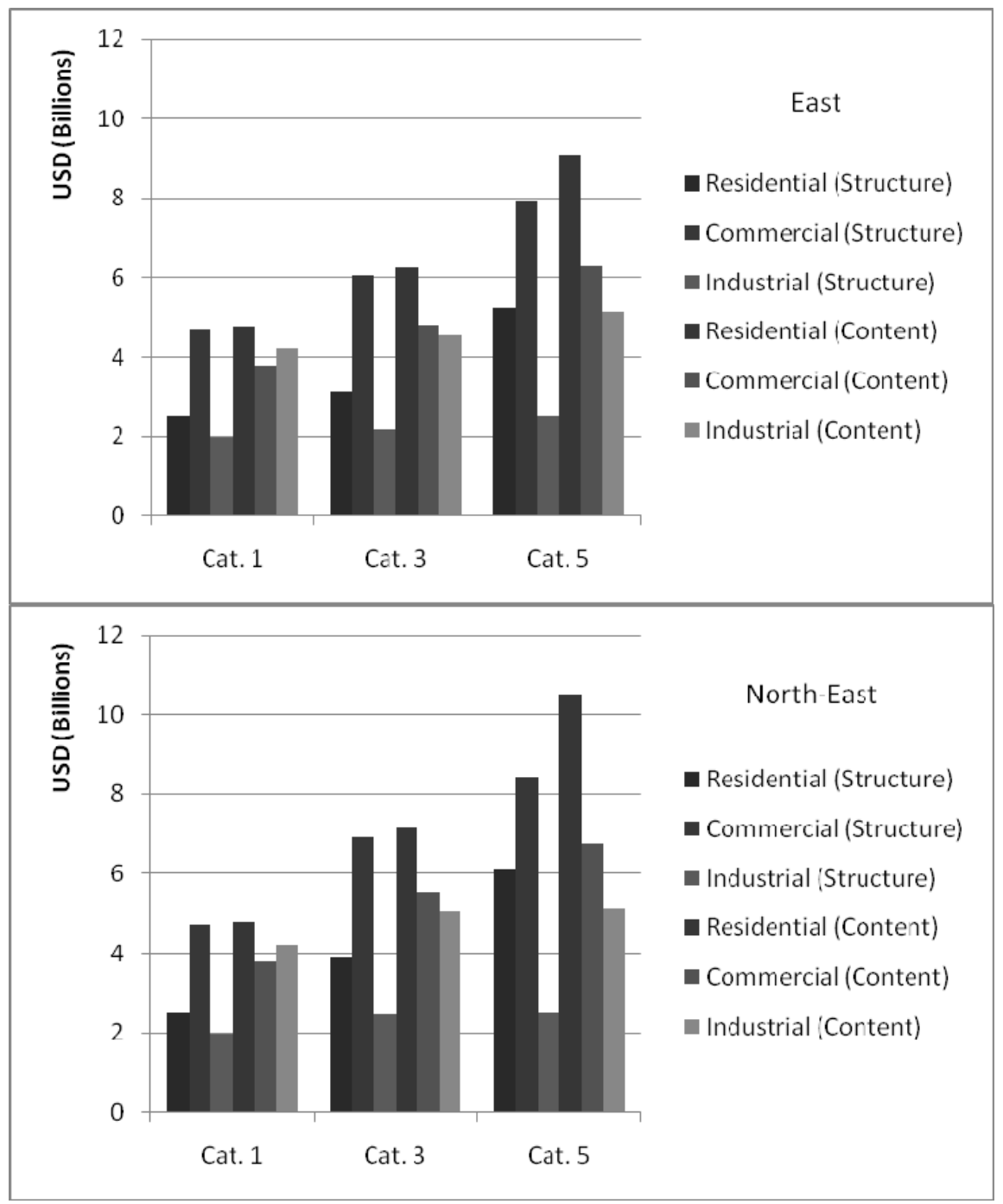

Fig. 3. Direct damage (USD) estimation in Biscayne Bay for storm surge heading east (top panel) and north-east (lower panel), calculated for Categories 1, 3, and 5 for insured contents and structures.

\subsection{Non insured assets}

In the US and in many other countries, people can insure themselves against flooding and therefore, the potential flood damage is of great interest to insurance companies. These companies have thus created databases 
for insurable assets. As mentioned in Section 1, non-insurable assets, such as public infrastructure, are not included in the available data. However, to provide a balanced flood risk estimate, it is essential to include these properties. Since very little information is available on these assets, we refer to past studies in order to find a best guess estimates. Therefore, we used the well documented consequences of the Katrina landfall in New Orleans to help assess infrastructure losses, such as in the OECD report (Hallegatte et al. 2008).

The OEDC report concludes that uninsured losses (infrastructure plus state facilities) represent about $40 \%$ of insured losses (residential houses and private properties plus business and commercial activities). Therefore, all the previous outcomes had to be increased by $40 \%$, leading to even larger losses. For a storm with an east direction, losses (building plus contents) are between a minimum loss of 30 billion USD for a Category 1 storm (e105i2) and 50 billion USD for a Category 5 storm (n525i2) (see Figure 4).

The worst-case scenario that we can hypothesize is a Category 5 storm with a north direction and with $25 \mathrm{mph}$ forward speed, which leads to total losses of 118 billion USD. Because of the damage function we chose (see Section 3.1), we assume that our damage evaluation is probably overestimated, especially when considering the areas on the beach front (where most of the buildings are skyscrapers).

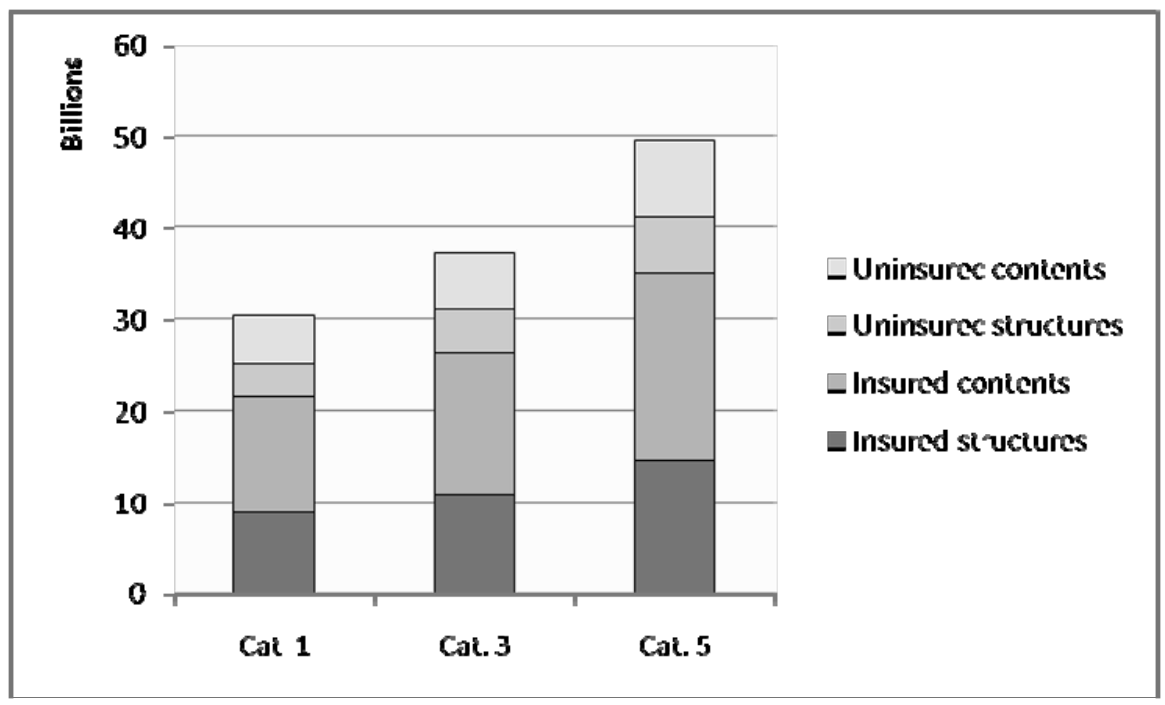

Fig. 4. Insured and uninsured losses for Category 1, 3, and 5 hurricanes, heading east. 


\section{Assessing risk reduction measures}

The previous analysis provided estimates for potential losses and exposure, information which is required to design optimal flood protection through cost-benefit analysis or risk management strategies. The final step of our analysis will be the evaluation of the potential damage when hypothetical protections are built in order to evaluate the benefits from dams and technical defence in the area.

There are three main kinds of vertical shoreline walls used as a protection from storm surges and high tides: seawalls, bulkheads, and revetments. The differences between the three are in their protective function. Seawalls are designed to resist the forces of storm waves; bulkheads are to retain the fill; and revetments are to protect the shoreline against the erosion caused by light waves (U.S. Army Corps of Engineers 1984).

The counties of Miami Dade and Broward have a long coastline that needs to be protected. According to a study of the Pacific Institute on California (Heberger et al. 2000), we can theorize that the cost of building a seawall can be of approximately 1600 USD per meter (in year 2000). A new levee between 3 and 5 meters in height would cost about 460 USD per meter. We can therefore estimate that about $200 \mathrm{~km}$ long coast will need to be protected and therefore the cost of constructing a coastal flood protection can be lower than 1 billion USD. In a full cost-benefit analysis of a protection system, monetary costs are not the only costs that need to be taken into account. The visual and physical impacts of protections on the beach also need to be considered because they can make the area less attractive with consequences on economic activities (e.g., tourism) and on quality of life and amenities. In addition, negative consequences on biodiversity and ecosystems are likely.

A full analysis of Miami protection would thus require (i) carrying out a detailed analysis of non-monetary costs of protection infrastructure; and (ii) the consideration of alternative protection measures, in particular, ecosystem-based protection. The current protection policy, based on beach nourishment, goes in this direction, but - as will be shown below - can hardly protect the city against the largest storms.

We made four different basic assumptions hypothesizing different scenarios of intervention: doing nothing, building 2-meter-high dikes, building 3.5-meter-high dikes, and building 5-meter-high dikes to completely protect the area from flood losses.

Unchanged protection: In the current situation, a storm surge, in absence of protection, will lead to losses between 30 billion up to 118 billion 
USD for a Category 5 storm, as described in the previous section. It can be assumed that some natural or artificial protections do exist in the area, even if we do not have information about their size and protection capacity. Therefore, this result has to be considered as an overestimation.

2-meter protections: It is difficult to assess the consequences of protection overtopping. Some protection would collapse in case of overtopping, while others are able to support overtopping and keep reducing the water flow within the protected area.

In this analysis, we apply a strong simplification and we assume (i) that all the areas with water levels below 2 meters are not flooded thanks to the protection; and (ii) that in areas with water levels beyond 2 meters, the water level is reduced by 2 meters thanks to the protection. So, where water levels in absence of protection are 5 meters, the protection reduces the flood to 3 meters. This is an optimistic assumption since we suppose that protections remain partly effective in case of overtopping.

A 2meter dam would completely protect from all Category 1 storm surges. A storm surge of Category 3 heading east has a residual damage of 10 and $8 \%$ per structure and content of residential building and between 16 and $1 \%$ for the commercial and industrial ones (compared with losses in absence of protection). A Category 3 heading north-east will have a residual damage of $25 \%$ for residential structure and of 26 and $13 \%$ for the commercial and industrial ones.

For a Category 5 storm surge, the 2 meter protection is not completely helpful since the percentage of damage being above 2 meters corresponds to $27 \%$ for a storm heading east, with a residual loss of about 10 billion USD, and $31 \%$ for a storm heading north-east, with a residual loss of 12 billion USD. A storm surge of Category 5 heading north has a residual damage of $66 \%$ and the potential loss is 56 billion USD. Moreover, in these circumstances a protection collapse is also possible, since the protections will be overtopped. Therefore, a 2-meter protection could be a suitable protection in case of smaller surges, for example to spare the 22 billion USD of damages caused by a Category 1 storm heading east, but it does not offer an adequate protection for events of major dimension.

3.5-meter protections: A 3.5-meter dam would completely protect from all Category 1 and Category 3 storm surges. Considering Category 5 storms and once again the previous examples, we calculated that, with a protection of 3.5 meters, the flood risk for storm surges heading east and north-east is completely removed. The residual damage is still quite high in case of storm surges of Category 5 heading north, north/north-east, north-west, west, west/north-west and west/south-west. Each of them still 
have a residual damage of 9 to $11 \%$ and the potential residual loss is between 8 and 11 billion USD.

This partial overflowing could possibly be contained with further flood control structures and defences (e.g., successive dike rings), drainage infrastructure, and beach nourishment interventions.

Figure 5 shows that most of the damage, both in structure and contents, is distributed before the 2- and 3.5- meter level, in the case of a Category 5 heading north hurricane.

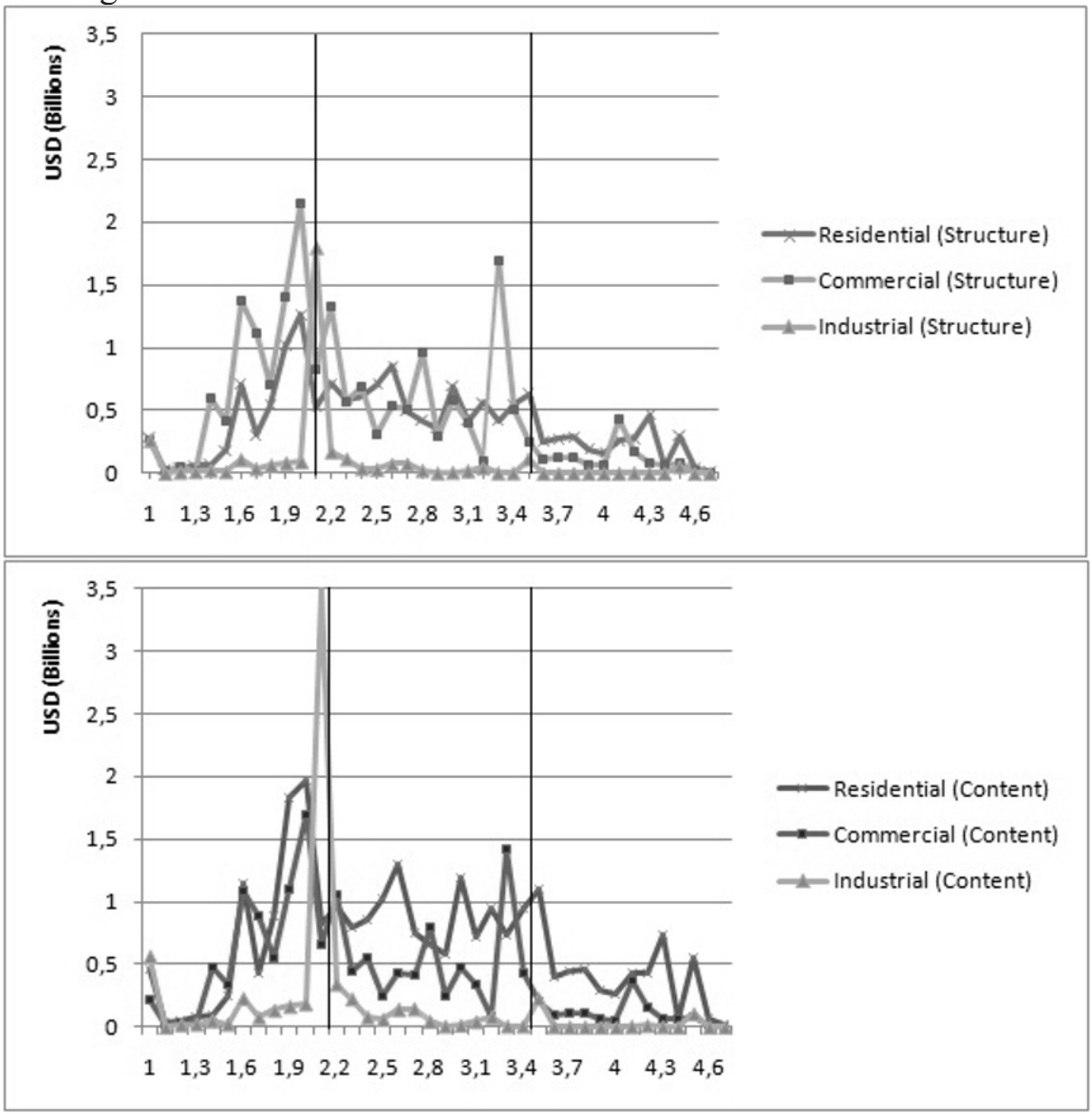

Fig. 5. Economic damage in each flooded area at a given water level caused by a Category 5 heading north hurricane, for structures (top panel) and contents (lower panel).

Completely removing flood risk (5-meter protections): In case of a Category 5 storm, water levels reach levels of about 5 meters and the protection to cope with these events would need to be extremely high and ro- 
bust. Even though a full cost-benefit analysis of such a protection is out of the scope of this paper, protecting Miami against all possible storms would probably be extremely expensive, especially because of non-monetary costs, in particular the welfare cost of living behind high walls.

In fact, very high dams would completely eliminate the visual and physical access to beaches. Moreover, in general a hardfill dam requires a basement which is three times the height of the dam itself (ICOLD 1992). This means that a very high dam would require an enormous quantity of space on the beach. On one hand, this solution appears not to be conceivable in an area where tourist attractiveness is the basis of the local economic system. Tourism is the first economic sector in the state and 1.3 million Florida jobs are directly or indirectly related to tourism. The sector - and thus the rest of Florida's economy- is at risk of risk perception shifts due to large disaster. Therefore the impact of protections on the tourist sector can be twofold and has to be carefully investigated.

\section{Conclusions}

This analysis uses the SLOSH storm surge model and suggests a methodology for assessing direct flood damage potential using a land use database combined with flood extent, flood depth, and economic asset data. We calculated that, in the case of a Category 5 hurricane (as illustrated in Figure 1), water levels can reach about 5 meters in height and potential losses larger than one hundred billion USD and this is without taking into account wind damages. Thus, additional protection seems desirable, even though protecting against all possible events appear simply impossible.

Regardless of their height, it is important to mention that coastal flood defences should not consist only of dams. In Section 1, we showed that beach nourishment interventions are already taking place. There are other options, including: elevating existing areas, building sea walls and flood control structures, and encouraging relocation (Harrington and Walton 2008). Moreover the presence of dams and sea walls requires efficient drainage infrastructure to prevent the city from being flooded by heavy rainfall and surges. In particular, in the presence of high dams, a move from gravity drainage to pumps may be necessary. As a result, protection against storm surge risks must be made in conjunction with improved rainfall flood management.

Furthermore, additional market and non-market impacts of coastal protections should be taken into account while calculating protection costs. Market impacts include the functioning of the harbour, dam maintenance, 
drainage, and pumping infrastructures, while non-market impacts include aesthetic considerations and city attractiveness (Hallegatte et al. 2008). In the case of large dikes, these costs may become considerable and will need to be weighed against the benefits of higher protection. Of course, building dams on the beach front may have negative aesthetic effects and may potentially impact city attractiveness and consequently the tourism industry.

Even once appropriate protective measures are built, protections have to be maintained rigorously, since the consequences of a failure or overflowing would be very large. It also highlights the need to adopt emergency plans and warning systems to avoid large human casualties in case of failure. Flood defence upgrades and innovations appear urgently needed in the current context; climate change and sea level rise will make them even more warranted.

Additionally, the design of future protection has to take into account future sea level rise projections due to climate change. Considering the uncertainty of future sea levels and flood risk, adaptation to climate change and to storm surge flood prevention have to be designed together.

It will also be important to build defences in a way that allows for flexibility taking into account the uncertainties in projections and making it possible to upgrade them if sea level rise is larger than expected. In particular, all planning and new infrastructure investments must take account of the risk over the entire lifetime of the investment to reduce unnecessary capital replacement costs.

The present analysis has several caveats which have to be highlighted when considering these results. The assessment of economic impacts associated with coastal flooding has been simplified in several ways. In particular, the damage function has not specifically built for this region. Flood defences have not been explicitly modelled and the consequences of an overflow are not represented in any detail. Flood risks are very different depending on whether an overtopping leads to defence collapse or not. Also, there is large uncertainty concerning damages to infrastructure and other uninsured properties. Most importantly, indirect losses (e.g., business interruption, economic feedbacks) are not included in this analysis, which also disregards important dimensions of social well-being (e.g. casualties, illness, psychological trauma, disruption of social networks, loss of national competitive strength and market positions, loss of cultural heritage, city attractiveness, etc.).

We do not know how population and assets will evolve in Miami over this century. Further studies are necessary to determine how and according to which trends people and buildings will be located in the future. Depending on urbanisation plans and land-use regulations, more buildings can translate or not into a higher exposure. As a consequence, much more 
work on the vulnerability of Miami is needed and will be carried out in a follow-up study.

\section{Acknowledgements}

We would like to thank Auguste Boissonnade and Robert Muir-Wood from RMS and Edida Rajesh from RMSI for providing us the economic data on asset exposure, and Nicola Ranger from LSE for her advices on vulnerability curves.

\section{References}

Emanuel K.A. (2008). "Hurricanes and Global Warming: Results from Downscaling IPCC AR4 Simulations", Bulletin of the American Meteorological Society.

Genovese E. (2006). A methodological approach to land use-based flood damage assessment in urban areas: Prague case study, Technical EUR Reports, EUR 22497 EN.

Green C. (2003). Handbook of Water Economics: Principles and Practice, John Wiley and sons, Chicester, $443 \mathrm{pp}$.

Hallegatte, S., J.-C. Hourcade, and P. Dumas (2007). Why economic dynamics matter in assessing climate change damages: illustration on extreme events, Ecological Economics, 62, 330-340.

Hallegatte S., N. Patmore, O. Mestre, P. Dumas, J. Corfee Morlot, C. Herweijer, R. Muir Wood (2008). Assessing Climate Change Impacts, Sea Level Rise and Storm Surge Risk in Port Cities: A Case Study on Copenhagen, OECD Environment Working Paper No. 3, 2008 (2).

Hallegatte S. and V. Przyluski (2010). The economics of natural disaster, CESifo Forum 2/2010, pp. 14-24.

Harrington J., and Walton T. L. (2008). Climate change in coastal area in Florida: sea level rise estimation and economic analysis to year 2080, Florida State University report.

Heberger M., H. Cooley, P. Herrera, P. H. Gleick, E. Moore (2009). The impacts of sea-level rise on the California coast, California Climate Change Center, Pacific Institute, August 2009.

Herweijer C, Nicholls R. J., Hanson S, Patmore N, Hallegatte S, CorfeeMorlot J, Chateau J, Muir-Wood R (2008). "How do our coastal cities fare under rising flood risk?", Catastrophe Risk Management, April, 12-13. 
ICOLD (1992). Cost Impact on Future Dam Design - Analysis and Proposals, ICOLD publications, No. 83.

ICLEI (2009). Perspectives on water and climate change adaptation. Local government perspective on adapting water management to climate change.

http://worldwatercouncil.org/fileadmin/wwc/Library/Publications_and reports/Climate_Change/PersPap_07._Local_Government.pdf

IPCC (2007). Climate Change 2007: The Physical Science Basis. Contribution of Working Group I to the Fourth Assessment Report of the Intergovernmental Panel on Climate Change [Solomon S, Qin D., Manning $\mathrm{M}$, Chen Z, Marquis M, Averyt K B, Tignor M, Miller H L (eds.)]. Cambridge University Press, Cambridge, United Kingdom and New York, NY, USA, 996 pp.

Kron W. (2003). High water and floods: resist them or accept them? In: Schadenspiegel (Losses and loss prevention), 46th year. No.3. 26-34. Munich Re Group, Munich.

Landsea C. W. (2005). "Hurricanes and global warming". Nature, 436, 686-688 (2005).

Lugeri N., E. Genovese, C. Lavalle, A. De Roo (2006). Flood risk in Europe: analysis of exposure in 13 Countries, Technical EUR Reports, EUR $22525 \mathrm{EN}$.

Lugeri N., Kundzewicz Z.W., Genovese E., Hochrainer S., Radziejewski M. (2010). River flood risk and adaptation in Europe: assessment of the present status. Mitigation and Adaptation Strategies for Global Change International Journal, Volume 15, Number 7, 621-639.

Nicholls, R.J., S. Hanson, C. Herweijer, N. Patmore, S. Hallegatte, J. Corfee-Morlot, J. Chateau, R. Muir-Wood (2007). Screening Study: Ranking Port Cities with High Exposure and Vulnerability to Climate Extremes, OECD Working Paper, at http://www.oecd.org/document/56/0,3343,en_2649_201185_39718712 1_1_1_1,00.html

Pfeffer, W. T., Harper, J. T., O’Neel, S., (2008). Kinematic constraints on glacier contributions to 21st-century sea-level rise, Science, 321(5894): $1340-1343$

Rahmstorf (2007). Sea-Level Rise A Semi-Empirical Approach to Projecting Future, Science 315, 368-370, DOI: 10.1126/ science.1135456.

Smith, D. I. (1994). Flood damage estimation - A review of urban stagedamage curves and loss functions, Water SA, 20(3), 231-238, 1994.

United States Army Corps of Engineers (1984). Shore Protection Manual, Volumes 1\&2. Waterways Experiment Station, Coastal Engineering Research Center, Vicksburg,

Mississippi. 
Van der Sande C.J., de Jong S.M., de Roo A.P.J. (2003). A segmentation and classification approach of IKONOS-2 imagery for land cover mapping to assist flood risk and flood damage assessment, International Journal of Applied Earth Observation and Geoinformation, pp. 217-229.

Webster, P.J., G.J. Holland, J.A. Curry, H.-R. Chang (2005). "Changes in Tropical Cyclone Number, Duration, and Intensity in a Warming Environment", Science, 309, 1844,1846, 16 September 2005.

White G.F. (1945). "Human Adjustments to Floods: A Geographical approach to the Flood Problem in the United States", Doctoral Dissertation and Research paper no. 29, Department of Geography, University of Chicago. 


\section{严 Springer}

http://www.springer.com/978-3-642-19788-8

Advancing Geoinformation Science for a Changing World (Eds.)S. Geertman; W. Reinhardt; F. Toppen 2011, X, 520 p. 205 illus., 20 in color., Hardcover

ISBN: $978-3-642-19788-8$ 